\title{
Sacred Trust or Sacred Right?
}

Jeffrey Shulman

Georgetown University Law Center, shulmanj@law.georgetown.edu

This paper can be downloaded free of charge from:

https://scholarship.law.georgetown.edu/facpub/1377

http://ssrn.com/abstract=2497632

Jeffrey Shulman, Sacred Trust or Sacred Right? in THE CONSTITUTIONAL PARENT; RIGHTS, RESPONSIBILITIES, AND THE ENFRANCHISEMENT OF THE CHILD: (New Haven, Conn.: Yale University Press, 2014)

This open-access article is brought to you by the Georgetown Law Library. Posted with permission of the author. Follow this and additional works at: https://scholarship.law.georgetown.edu/facpub

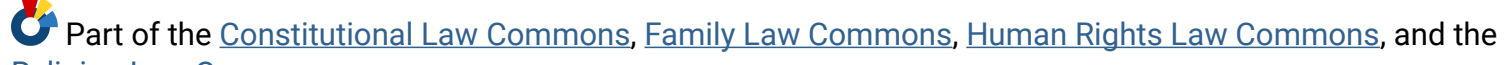
Religion Law Commons 


\title{
Sacred Trust or Sacred Right?
}

\author{
Some natural tears they dropp'd, but wip'd them soon; \\ The World was all before them, where to choose \\ Thir place of rest, and Providence thir guide: \\ They hand in hand with wand'ring steps and slow, \\ Through Eden took thir solitarie way. \\ - John Milton, Paradise Lost
}

\begin{abstract}
7 dward Walker was a minor when, in 1838 , he went to work at sea. Upon 1 his return, his father, Joseph Walker, claimed Edward's wages for his own use. Joseph made what charitably might be called a private settlement with the owner of the Etna, the ship on which Edward had served. Edward disputed the settlement, claiming the wages as his own. The federal district court made note of the general proposition that a father was "entitled to the earnings of his child by virtue of his paternal power." On this ground, Joseph had the right to settle matters on such terms as pleased him. The general proposition, however, was not as legally dispositive as he would have hoped. ${ }^{1}$

The court distinguished between the rights and duties of a father. While a father's duties were "indissolubly attached to the paternal relation," the same could not be said of a father's rights. The rights of the father, according to the court, are given to him by the state to enable him to fulfill his parental duties ("to provide for his child a home, to protect, to maintain, and to educate him according to the measure of his ability"), and, as a more concrete compensation, the father is allowed "to take the fruits of his child's labor." But this paternal power is not a "sovereign and independent
\end{abstract}


authority." It is not, to use the court's comparison, like the patria potestas enjoyed by the father in ancient Rome, "whose law held children to be the property of the father, and placed them in relation to him in the category of things instead of that of persons." This sovereign paternal authority, the court declared, "has never been admitted by the jurisprudence of any civilized people." Rather, the father holds only a contingent authority, "subject to the restraints and regulation of law," contingent because it is "inseparably connected with the parental obligations, and arises out of them." In short, paternal power rests on the fulfillment of paternal duty. Relying on a deep pool of legal theoreticians, treatise writers, and jurists, including "[t]he soundest and most esteemed commentators upon the common law," the court affirmed what, by the time of this dispute, was a well-settled legal precept: The power of the parent, because it derives directly from the duty to benefit the child, is limited in scope and duration. It is only as great as is needed to secure the child's welfare: "It is not a power granted to the parent for his benefit, but allowed to him for the benefit of the child, and it ceases when the faculties of the child have acquired that degree of maturity, that it may safely be trusted to its own resources. When, therefore, the parent abuses this power, or neglects to fulfil the obligations from which it results, he forfeits his rights." 2

For, at bottom, the child does not belong to the parent. The court stressed that Edward, like all children, was endowed with a social nature and was destined for the enjoyment of a social life. As a member of what the court called "the human family," Edward was invested - endowed by birthright, as it were - with all the rights that belong to other members of this universal family. The court explained,

The Creator of man, in giving to [the child] a social nature and endowing him with those qualities which fit him for the enjoyment of social life, has imposed upon the parent, as one of the conditions of his being, the obligation of providing for his offspring while they are incapable of taking care of themselves. But his children are not on that account born slaves. They do not become the property of the parent. As soon as a child is born, he 
becomes a member of the human family, and is invested with all the rights of humanity.

Thus, when the parent fails to fulfill his duty, when he fails to honor the human rights and social nature of the child, the "protecting justice of the country" will interpose and deprive him of his authority. The court was "not aware of any doubt" that the state could take children from their parents and place "them under the care of persons proper to have the control of them, and to superintend their education." Indeed, it was the legal and moral responsibility of the court "to remove a guardian who is unfaithful to his trust."3

It is commonly assumed, by academic and lay audiences alike, that parents have long enjoyed a fundamental legal right to control the upbringing of their children, but this reading of the law is sorely incomplete and anachronistic. Cases like that of Edward Walker suggest that if by "fundamental" we designate rights with a deep historical pedigree, the right to parent free from state interference cannot be numbered among them. What is deeply rooted in our legal traditions and social conscience is the idea that the state entrusts parents with custody of the child, and the concomitant rule that the state does so only as long as parents meet their legal duty to take proper care of the child. Whether custodial authority was called a power or a right, ${ }^{4}$ it was made contingent on the welfare of the child and the needs of the state. "[T] he right of parents, in relation to the custody and services of their children," Joseph Story wrote in 1816, "are rights depending upon the mere municipal rules of the state, and may be enlarged, restrained, and limited as the wisdom or policy of the times may dictate." Custodial authority, maintained the nineteenth-century libertarian treatise writer Christopher Tiedeman, "is not the natural right of the parents; it emanates from the State, and is an exercise of police power." 5

These assertions of the ordinariness of parental authority are not isolated instances. Reviewing the case law of the nineteenth century, Lewis Hochheimer, whose treatise on the law of child custody was a familiar reference for courts in the late nineteenth and early twentieth centuries, concluded that "[ $\mathrm{t}]$ he general result of the American cases may be characterized as 
an utter repudiation of the notion, that there can be such a thing as a proprietary right of interest in or to the custody of an infant." ${ }^{\prime 6}$ It is true of our legal past - as it is true today - that claims of right (natural and civil) were advanced in support of parental power. ${ }^{7}$ But, as Hochheimer tells us, the prevailing legal current, driven by the equitable force of trust principles, swept away such "narrow contentions": "The entire tendency of the American courts is, to put aside with an unsparing hand all technical objections and narrow contentions whereby it may be attempted to erect claims of supposed legal right, on a foundation of wrong to persons who are a peculiar object of the solicitude and protecting care of the law." 8

Traditionally, for both legal scholars and jurists the very word "trust" was something of a linguistic charm to ward away rights-thinking. For James Kent, the duty to provide for the maintenance and education of the child is "a sacred trust"; it is the "true foundation of parental power," the source of the authority that the law "has given" to parents. The parent is "absolutely bound" to serve the child. For Story, parents are only "entrusted with the custody of the persons and the education of their children" and only as long as they properly take care of the child. "Why," Story asks, "is the parent by law ordinarily entrusted with the care of his children?" His is a simple answer: "Simply, because it is generally supposed, that he will best execute the trust reposed in him; for, that it is a trust, and of all trusts the most sacred, no one can well doubt." For Hochheimer, proprietary principles were a legal remnant of an antiquated family law; in their place the law had substituted "the idea of trust as the controlling principle in all controversies in relation to such custody." "In true legal conception," he writes, "[the parent] is simply the agent or trustee of the government." For Tiedeman, "[t]he parent has no natural vested right to the control of the child"; parental control is "in the nature of a trust, reposed in [the parent] by the State ..., which may be extended or contracted, according as the public welfare may require." Likewise, and quite early in our juridical history, courts were equally committed to the word and the concept. ${ }^{10}$ By the mid-nineteenth century the jurisdiction of the courts "to remove infant children from the custody of their parents, and to superintend their education and maintenance" was not only "well established" but also considered "indispensable to good order and the 
just protection of society." This jurisdiction "proceed[ed] upon the theory that the right of guardianship is a trust for the benefit of the child, and the parent is not at liberty to abuse it." 1

On this basis, the Etna court was fully prepared to protect the interests of Edward Walker against the claims of his father. When parents fail "to fulfil the obligations from which [parental power] results," the court observed, the state-as parens patriae, as parent of the country-has a "deep interest" to ensure that its grant of authority is not abused. ${ }^{12}$ Joseph Walker, it turned out, had not fulfilled the responsibility entrusted to him, and the court awarded Edward his just compensation.

Under a trust model of parent-child relations, biology does not beget rights. It begets responsibilities. The trust model is built on the Lockean principle that it is the child who has a fundamental right (what William Blackstone called a "perfect right"): the right to appropriate parental care, including the entitlement to an education that will prepare the child for eventual enfranchisement from parental authority. To Locke, the "right of Tuition" is "rather the Priviledge of Children, and Duty of Parents, than any Prerogative of Paternal Power." ${ }^{3}$ (It is a noteworthy piece of American legal history that the child's entitlement to a proper education and the consequent affirmative duty of the state to provide a proper public schooling - a striking break with negative constitutionalism - have long been enshrined in our states' political charters.) ${ }^{14}$ What biology begets is a duty to ensure the child's best interests. "The terms 'right' and 'claim,' when used in this connection [that is, the custody of children]," declared Hochheimer, "according to their proper meaning, virtually import the right or claim of the child to be in that custody or charge which will subserve its real interests." ${ }^{5}$ In this connection, then, custodial authority is not a right at all. It is, Hochheimer tells us, "a grant of power flowing from the state, a portion of the state's protective care and guardianship." 16

The idea that, historically, American law embodied a strict regime of parental rights is not easily dislodged. As formidable a scholar as Martha Fineman has written that, "[h]istorically, fathers were entitled to possession of their children. . . . In essence, fathers had an absolute right to their 
children, 'owning' them as if they held 'title' to them." 17 Yet the American legal tradition is one that treated paternal absolutism and its rights foundation as barbaric. ${ }^{18}$ "That the father had any such absolute right to the care and custody of his children," that the state lacked the authority to "control the conduct of the father in the education of his children" - these propositions, Story wrote, "would strike all civilized countries with astonishment."19 This confident delimitation of the parent's "ordinary" rights is nowhere better seen than in child custody cases, where courts challenged, first, paternal authority and, then, parental control of the child generally. At common law the father was entitled to the value of his minor children's labor and services, a valuable asset, no doubt; ${ }^{20}$ but he was entitled to the benefit of the child's labor "in order the better to discharge his duty." ${ }^{21}$ Custody courts would not presume that, in fact, the parent was appropriately fulfilling the demands of his role; instead, they would "act according to sound discretion," consulting the child "if it be of sufficiently mature age to judge for itself." 22 Where the child was too young to choose for itself, it was a judicial commonplace that "the real interest of the child is the principle which must govern." 23 The parent retained custody of his-or, as the law evolved, her-minor children, but this privilege was granted on the presumption that parents act in the best interests of the child - and this was a rebuttable presumption. The parental entitlement was good only "so long as [the parent] discharges the obligation imposed upon him by social and civil law." ${ }^{4}$ It is sometimes argued that the paramount right of the parent to direct his child's upbringing without state intervention, absent a showing of harm, was so basic as not to need express constitutional protection. In fact, what was so basic was parental obligation - "[T]he obligation of parental duty is so well secured by the strength of natural affection," as Kent wrote, "that it seldom requires to be enforced by human laws" 25 - and American custody courts, only too content to compare their law with the harsh and technical rules of the English cases, had little taste for a harm standard. ${ }^{26}$

Far from being absolute, the right of the parent was not even the custody courts' primary consideration. "The true view," as one mid-nineteenthcentury court put it, "is that the rights of the child are alone to be considered, and those rights clearly are to be protected." The very idea that parents 
have rights as parents was called into question. The New York Court for the Correction of Errors was not alone when it declared that "there is no parental authority independent of the supreme power of the state. But the former is derived altogether from the latter." If parental authority is derived from the state, the parent does not obtain rights merely by virtue of being a parent. "It is an entire mistake," Story concluded, "to suppose the court is at all events bound to deliver over the infant to his father, or that the latter has an absolute vested right in the custody." Similarly, the Supreme Court of Pennsylvania: "[T]he right of parental control is a natural, but not an unalienable one." 27

Rather, the parent obtains authority, however it is styled, over the child by virtue of acting as a parent. Indeed, it is the child's entitlement-the child's right "to be surrounded by such influences as will best promote its physical, mental, and moral development" - that was thought to be in the way of a natural vested right. In contrast, the right of the parent "to surround the child with proper influences [was] of a governmental nature," in the sense that parental authority over the child was considered a benefit granted by the state in return for parental care of the child. ${ }^{28}$ This benefit was subject to the principle-again, the debt is to Locke-that what is due the child is defined, in a general sense, by basic developmental needs and, more particularly, by the developmental needs of the child destined from birth to be a member of a liberal constitutional order. Accordingly, the metes and bounds of parental duty were not considered a matter solely for private determination. (Nor, for that matter, were the legal parameters of filial duty. ${ }^{29}$ Parents in a liberal society, it was assumed, have no right to parent as they see fit.

In the law, there are rights and then there are rights. Not all rights are created equal. Most laws or other forms of state action receive a deferential review from the courts, despite the fact that they might impinge upon a host of personal prerogatives. Under rational basis review, courts presume the constitutionality of legislation. The party trying to overcome this presumption must show (1) that the law serves no legitimate purpose or (2) that the means employed by the law has no rational relation to the law's stated goal. 
But laws or other forms of state action that impinge upon rights considered to be fundamental get a far more skeptical judicial reception. Under a strict scrutiny standard, courts will presume that such a law is unconstitutional. To overcome this presumption, the government must show (1) that the law serves a compelling purpose and (2) that the means employed by the law are as narrowly tailored as possible to achieve the law's stated goal. Because the hurdle of strict scrutiny is so difficult to clear ("strict in theory and fatal in fact," it is commonly, if not entirely accurately, said), the level of review employed by the court can easily dictate the outcome of a case. ${ }^{30}$ So, it is a high-stakes determination whether a right is fundamental or not.

The right to parent would be considered an unenumerated right, implicitly protected by the Fifth and Fourteenth Amendments of the United States Constitution (and, both before and after the passage of the Fourteenth Amendment, by state constitutional analogues). ${ }^{31}$ The "liberty" of the Due Process Clauses safeguards those substantive rights "so rooted in the traditions and conscience as to be ranked as fundamental." These are rights, like the enumerated freedom of speech, that are considered "of the very essence of a scheme of ordered liberty." ${ }^{2}$ Inevitably, whether an unenumerated right is so rooted and so essential will be a contested, and probably fiercely contested, question. Inevitably, this is a query with both descriptive and normative dimensions. Has the right to parent traditionally been treated as fundamental? Should the right to parent be treated as fundamental? This book answers no to both questions.

The right to parent as a matter of constitutional law is especially tenuous. The Supreme Court has echoed the popular assumption that the right of parents to make decisions concerning the care, custody, and nurture of their children is a fundamental one, time-honored ("perhaps the oldest of the fundamental liberty interests recognized by this Court") and honored by the work of the Court ("[W]e have recognized the fundamental right of parents to make decisions concerning the care, custody, and control of their children"). ${ }^{33}$ But no Supreme Court holding supports this claim. No decision, including the case that is the source of the far-reaching assertions just parenthetically quoted, has held that the right of parents to make decisions concerning the care of their children is a fundamental one. If the 
rigor of the Court with regard to the regulation of parental authority has varied, ${ }^{34}$ its scrutiny has never been strict. In fact, as Justice Antonin Scalia has observed, there is little decisional support for the notion that the right to parent is a "substantive constitutional right" at all, let alone a fundamental one. ${ }^{35}$ More than once, the Court has declined the opportunity to adopt this position. $^{36}$

In 1923, in Meyerv. Nebraska, the Court struck down a Nebraska law that prohibited both the use of foreign languages as a medium of instruction and the study of foreign languages before the eighth grade. These restrictions applied to any school, public or private. In 1925, in Pierce v. Society of Sisters, the Court struck down Oregon's Compulsory Education Act, which required attendance at public schools. Neither case was really brought to the Court as, primarily, a matter of parental rights - a litigation choice that itself should call into question the well-rootedness of such rights; nonetheless, in both cases the court concluded that, under the Due Process Clause of the Fourteenth Amendment, the state laws unreasonably interfered with the liberty of parents to direct the upbringing and education of their children. ${ }^{37}$

But Meyer and Pierce both accept as uncontroversial the principle that the state can define and enforce the parental duty to educate. The Meyer Court did not question the authority of the state "to compel attendance at some school and to make reasonable regulations for all schools, including a requirement that they shall give instructions in English." ${ }^{38}$ Here, the Court reviewed a law that "sought not to require what children must learn in schools, but to prescribe, in the first case, what they must not learn." 39 The question Meyer considers is how far the state can go in dictating what the parent can and cannot do. ${ }^{40}$ The Court answered that the state may not set up a standard of education and then prohibit any additional or supplemental instruction. If there is a fundamental right at stake in Meyer, it is the right of the parent, "after he has complied with all proper requirements by the state as to education, to give his child such further education in proper subjects as he desires and can afford." ${ }^{41}$ In Pierce, the Court pointedly noted that the case raised no question "concerning the power of the state reasonably to regulate all schools," a power that included a very substantial measure of curricular control ("that certain studies plainly essential to good 
citizenship must be taught, and that nothing be taught which is manifestly inimical to the public welfare"). ${ }^{42}$ If there is a fundamental right at stake in Pierce, it is the right of the parent "to provide an equivalent education in a privately operated system." ${ }^{43}$ Broad claims are made for the legacy of these seminal due process cases, ${ }^{44}$ but, as Justice Byron White put it, Meyer and Pierce "lend[] no support to the contention that parents may replace state educational requirements with their own idiosyncratic views of what knowledge a child needs to be a productive and happy member of society." 45

Meyer and Pierce were as much about rhetorical reach as legal doctrine. Their anti-statist sentiment would serve as a constitutional banner for those marching in support of parental rights. That the Court's support of a right to parent was the product of judicial activism at its most active - indeed, the product of a "modern" jurisprudence (built on "more correct ideas" and "a truer conception" of the proper functions of government) that would, in a self-conscious break with legal tradition, set the stage for a new era of unenumerated privacy rights - did not (and does not) deter conservative advocates of parental rights from celebrating the cases that rested on this due process basis. ${ }^{46}$ That this right was the product of a Lochner-era constitutionalism bent on restricting the police powers of the state-indeed, the product of a narrow, natural law individualism (built on the rejection of a centuries-old common law legacy of "paternal government") that would strike down basic health and safety regulations - did not (and does not) much bother liberal proponents of the right to parent. To parental advocates on both sides of the political spectrum, the prerogatives of parenting apparently ease concern about doctrinal consistency. ${ }^{47}$

Meyer and Pierce involved only the general interest of parents in the nurture and education of their children. Where nothing more is at stake, the Court has said, the state's authority outweighs due process objections. Often, though, more is at stake. Legal claims based on the right to parent often come packaged with claims based on other constitutional protections, most frequently and forcefully the Free Exercise Clause. Today, religious parenting rights enjoy a special constitutional protection from state regulation. State action that burdens religious parenting is subject to heightened judicial scrutiny. 
Why are restrictions on religious parenting rights subject to heightened judicial review? The obvious answer is that the right of religious freedom is considered fundamental, but this is only partially correct. The Supreme Court has said that state action restricting religious practice is constitutionally permissible unless such action directly targets religious practice or discriminates against religious groups. This is the core principle-a controversial one, to be sure-of Employment Division, Department of Human Resources of Oregon v. Smith. Decided in 1990, Smith held that where state regulation burdens religious freedom only incidentally - that is, where the burden is the incidental effect of regulation that is neutral and generally applicable, restricting secular and religious activity alike-the courts will presume its constitutionality. ${ }^{48}$ Thus, for example, a law that makes illegal the use of peyote because of safety and health concerns would be subject to, and would survive, rational basis review, even though it burdened the beliefs and perhaps effectively prohibited the practices of some religious groups.

Separately, then, neither the right to parent nor the right of religious freedom would trigger strict scrutiny. Combined, however, these rights form a tough legal firewall that protects parents from state interference in the religious upbringing of their children. For the Court has also said that when the interests of parenthood are combined with a free exercise claim, "more than merely a 'reasonable relation to some purpose within the competency of the State' is required to sustain the validity of the State's requirement under the First Amendment." ${ }^{49}$ This is the core principle, also a controversial one, of Wisconsin v. Yoder. Though Yoder was decided in 1972, its invention of a hybrid parenting/free exercise claim survived Smith, as did other variations on the hybrid rights theme. So, even after Smith, the First Amendment does require heightened scrutiny for claims that involve "not the Free Exercise Clause alone, but the Free Exercise Clause in conjunction with other constitutional protections," such as the right of parents to direct the upbringing and education of their children. In religious parenting cases, by some abstruse constitutional calculation, strict scrutiny becomes the norm, despite the fact that state action does not target religion or impinge upon a fundamental right. Under a strict scrutiny standard, courts will uphold state 
regulation of religious parenting only where "it appears that parental decisions will jeopardize the health or safety of the child, or have a potential for significant social burdens." 50 Thus, a law that requires parents to send their children to some form of secondary schooling would be subject to, and might not survive, strict scrutiny if the parents' objections to the compulsory education requirement are religiously motivated.

Writing for the Court in Smith, Justice Scalia cautioned that our society would be courting anarchy if every law or regulation of conduct that negatively affected someone's religious belief had to be supported by a compelling state interest. To excuse conduct contrary to a general law "“would be to make the professed doctrines of religious belief superior to the law of the land, and in effect to permit every citizen to become a law unto himself." 51 Accordingly, the Smith Court discussed hybrid rights as an exception to general constitutional principles. Yet in the universe of religious parenting cases, the exception swallows the rule; because such cases are hybrid by definition, strict scrutiny becomes the norm. The result, if hardly anarchy, is the creation of a separate sphere of the law-a constitutional anomaly, as Scalia described it - where the government's ability to protect children is subject to an individual parent's religious beliefs. (Unable to escape this unacceptable conclusion, the Yoder Court made a fainthearted attempt to limit its holding to the specific and peculiar facts of the case before it. $)^{52}$

If Yoder delivered a special right to religious parents, it did so at some cost to the parentalist cause. (I take the term "parentalist" from the strongly argued essay by Stephen Gilles titled On Educating Children: A Parentalist Manifesto. ${ }^{53}$ I use the term broadly to designate those who advocate a legal and moral regime of considerable deference to parental rights.) For the Court's decision means that the right to parent, by itself, does not enjoy a fundamental status, at least where state regulation of education is concerned. Only where the legal question involves the absolute termination of parental rights has the Supreme Court required that state action (specifically, a declaration of parental unfitness) meet the tough test of justification associated with strict scrutiny ${ }^{54}$ - though even here, as David Meyer has pointed out, the balancing of interests undertaken by the Court "is difficult to square neatly with the traditional strict-scrutiny formula." ${ }^{55}$ In 
2000, the Court had the opportunity to give parental rights a constitutional upgrade. In Troxel v. Granville, the Court considered whether a parent has the right to deny visitation rights to a child's grandparents. ${ }^{56}$ The decision badly disappointed those hoping for a fundamental rights victory. Though the Court used the language of fundamental rights, it did not conclude that strict scrutiny was the proper standard of review, settling instead for a mere presumption in favor of a fit parent's visitation choices.

With the Court speaking in uncertain tones, lower courts must contend with the fact that "the Supreme Court has yet to decide whether the right to direct the upbringing and education of one's children is among those fundamental rights whose infringement merits heightened scrutiny." Protection for parenting rights varies from jurisdiction to jurisdiction and from claim to claim; ${ }^{58}$ and courts have more than enough leeway to decide the merits of a case by choosing whether to apply a standard based on the best interests of the child (rational basis review) or a strict scrutiny harm standard. ${ }^{59}$ Given this state of affairs, it is not surprising that some parental rights advocates seek to amend the United States Constitution. The Parental Rights Amendment would declare that "[t]he liberty of parents to direct the upbringing and education of their children is a fundamental right," and, consequently, that strict scrutiny would be the standard of review in cases of alleged infringement. ${ }^{60}$

There are good reasons why the right to parent has not enjoyed a fundamental status in the law. To begin with, the right to parent is not one but many things, a bundle of different interests, each implicating the authority of parent and state in different ways and to different degrees. No surprise, then, that "[f]ar from the absolutist's assumption of strict scrutiny for every incursion, the Court's cases reveal a willingness, at least implicitly, to tailor the nature and strength of judicial scrutiny to the facts of each family privacy controversy." Yet all parental rights cases have one thing in common that even more emphatically cautions against strict scrutiny: They involve a third party, and one who is unable to defend its own interests. Other liberty interests establish a constitutional shield against governmental impairment of individual rights, but conflicts involving parental rights-Justice John 
Paul Stevens made this important if, one would think, self-evident point"do not present a bipolar struggle between the parents and the State over who has final authority to determine what is in a child's best interests." ${ }^{1}$ The interests of the child - who may well need the protection of the state, not protection from the state-and the state's interest in the child invariably affect the legal reckoning.

By its very nature, the supposed right to parent is a different creature from, say, the right of free speech. No one is required to speak responsibly. No one is required to speak at all. Yet would anyone object to the proposition that parents are required to exercise the right to parent responsibly? Or that a parent has no right not to parent? ${ }^{62}$ By definition, then, the parent's right to be let alone, to parent free from governmental interference, is and must be conditional and limited. ${ }^{63}$ Far from carrying with it a fundamental right, the decision to parent is inevitably a choice to forego rights otherwise available to adults. It is always a choice to give up to some extent, and often to a great extent, the right of individual choosing. There are compelling reasons why parents want to assume the weighty burden of child rearing, and there are good reasons why the state wants to give parents plenty of room to do their job; but parental authority over the child is not justified, not in our legal tradition and culture, by the proprietary interests of the parent as a rights-holder.

Obviously, not every break with the past is a bad thing; and, as Martha Minow reminds us, the case against rights can too easily be "levied by people who do not want to change existing patterns of hierarchy and domination." 64 Just as clearly, and our history unhappily bears more than sufficient testimony to this fact, the parens patriae authority of the state can be badly abused. To say that a parental rights orientation is not deeply rooted in our traditions, even to say that parental rights as a normative matter should not be considered fundamental, is not to declare that a particular policy decision is right or wrong. It is simply to say that it is a question of policy whether and how the state should regulate parent-child relations. Should we allow, say, parents to homeschool their children? Is homeschooling in the best interests of the child? Perhaps, perhaps not. Should we allow parents to spank their children? to compel religious observance, against the wishes of the 
child or against the wishes of a former spouse? to restrict visitation from third parties? The questions are as varied as the myriad duties parents undertake. If we think of parenting as a set of responsibilities, not rights, we will not all miraculously reach the same legal and cultural prescriptions - fiduciary principles do not inexorably lead in an antiparentalist direction; ${ }^{65}$ individually, the prescriptions we reach may not always fall into neat ideological (conservative or liberal) categories - but we will think of these questions as matters fit for democratic deliberation. To say that a parental rights orientation is not deeply rooted in our traditions is not to answer these questions. It is to ask them. But by giving parents the right to homeschool children or compel religious observance or restrict third-party visitation-or, more generally speaking, by giving parents the right to bring up their children as they want to-parental rights advocates would forestall public debate on contentious questions relating to the care and welfare of children. They would take these questions out of the public domain by keeping the home under constitutional lock and key. ${ }^{66}$ The question would no longer be one of the child's welfare but of parental entitlement.

This book looks at four related areas of the law: parental custody, state regulation of education, religion and parental rights, and nonparental thirdparty rights. In each,

1. historically, the authority of the parent has been treated as a sacred trust, a delegation of state power made on the presumption that it will be employed to promote the eventual enfranchisement of the child (this is the subject of chapter 2);

2. the emergence of a rights orientation has threatened to uncouple the traditional linkage of rights and responsibilities, subordinating the best interests of the child and the legitimate needs of the state to parental preferences (this is the subject of chapter 3); and

3. a renewed reliance on the trust model of parent-child relations would better serve both the developing personhood of the child and the civil society to which he or she belongs (this is the subject of chapter 4 ). 
In each area of the law, we face the same historical reality: It is the rights orientation that breaks with deeply rooted legal traditions and cultural values, rejecting time-honored trust principles of family law meant to protect both private and public interests. For the common law's careful calculation of privileges and duties; for its vision of children's needs as a source of positive claims on the state; for its sensitivity to evolving cultural mores, a focus on parental entitlement substitutes a negative rights wall behind which parents may bring up their children free from both state and nonstate interference. In this way, the "presentist" assumption that parental rights were always thus creates the entitlement mistakenly assumed to be a long-standing legal legacy. If we better understand that, as a descriptive matter, the right to parent is at odds with a cultural tradition of shared responsibility for the welfare of the child, we might be more ready to ask whether, as a normative matter, the right to parent should have a fundamental status in the law. We might be more willing to consider how old equitable principles can lead to new ways of accommodating the interests of parent, child, and state. ${ }^{67}$

On occasion the Supreme Court has put the trust model to productive use. In adjudicating the due process claims of unmarried fathers, for example, the Court has said that the rights of parents "are a counterpart of the responsibilities they have assumed." 68 This linkage of right and duty, according to the Court, is the true legacy of its seminal due process parenting cases. Constitutional parenthood embraces the Lockean principle that "[c]hildren are born to reason," and the law of nature commands a parental duty to secure for them "that equal Right that every man hath to his Natural Freedom, without being subjected to the Will or Authority of any other Man." ${ }^{69}$ On this commitment to the child's self-determination is predicated the Founders' theory of human dignity and, of particular salience for parent-child relations, the parallel theory of human development-the normative psychology of the law, we might say - that, taken together, sustain the Constitution's promise of personal as well as political freedom. ${ }^{70}$ It is the carrying out of this commitment that defines the trust assumed by parents and against which parental efforts must be constitutionally measured and rewarded. Our political charter does not allow for, in or outside the home, "a utopian conception of society according to which an order having been laid down all that remains to do is to conform to it." ${ }^{11}$ 
"Parental rights do not spring full-blown from the biological connection between parent and child," Justice Potter Stewart has said. "They require relationships more enduring." 72 But it is not every enduring parent-child relationship that merits constitutional protection. If this were the case, then compulsory schooling laws would fail against constitutional challenges brought by caring parents. Yet few would disagree that all parents are obligated to look after the educational welfare of their children. It is the trust model of parent-child relations that directs us to the particular charge that is the sine qua non of parental power: to secure the child's "equal Right" to intellectual and moral autonomy (Locke's "Natural Freedom”); or, more simply, to see that children, when they become adults, can choose what life they want to lead, what values they want to honor, what god they want to worship.

This duty presupposes that the child is free to form relationships with those outside the circle of the nuclear family. Hovering over the right to parent is the long-lingering shadow of a property entitlement. Today, the right to parent is fashioned as a right to personal autonomy, a right of privacy; yet it remains, essentially, a right to do what one wants with what is "mine." But if the child, at birth, "becomes a member of the human family," then parents are not free to seclude the child from outside influence. "If we ask ourselves what actually enables people to be autonomous," Jennifer Nedelsky writes, "the answer is not isolation, but relationships-with parents, teachers, friends, loved ones - that provide the support and guidance necessary for the development and experience of autonomy." Thus, our children are not and cannot be "ours," at least not exclusively, not permanently. ${ }^{73}$ (We ought to be as careful as Shakespeare with possessive pronouns. When Hermia awakes from her tumultuous midsummer night's "dream," she finds Demetrius "like a jewel / Mine own, and not mine own." $)^{74}$ From birth, children are members of a familial community outside and beyond the nuclear family; from birth, they are members of a political community outside and beyond the family. It is only by belonging that children can learn, by and for themselves, where they want to belong.

A trust model of parenting, with its assumption of shared authority over the child, need not evoke the specter of state paternalism. With regard to the child's upbringing, the state also is and also must remain merely an 
educational trustee. The liberal state holds what Locke calls a "Fiduciary Power to act for certain ends." " Like the parent's authority, the state's power over the child is conditional and limited. Ideally, the state, like the ideal parent, would cultivate the child's capacity to think and choose freely; it would foster the child's courage to challenge any closed set of values, public or private, liberal or conservative. The liberal state wants to pass on its traditions of freedom, equality, and tolerance, and no doubt the state, like real parents, can behave less than liberally toward its young people; but the surest way not to pass on these traditions would be to present them as moral absolutes to be accepted uncritically. ${ }^{76}$

For children, though, the threat to freedom of choice and conscience is no less grave when it comes from private orthodoxies, and the injury to the child caused by private coercion is no less grievous. In Meyer and Pierce, the Court feared that the state, through a regime of mandatory public education, would "standardize its children." ${ }^{77}$ Yet children sent to private schools or those kept at home might more easily suffer this fate. We are well cautioned by the pioneering scholar and children's advocate Barbara Bennett Woodhouse that "[s]tamped on the reverse side of this coinage of family privacy and parental rights are the child's voicelessness, objectification, and isolation from the community." 78 For this reason, courts should look skeptically at any educational scheme that seeks to restrict "the right to receive information and ideas." 79 The realm of intellect and spirit is invaded when children are forced to believe what other people believe, or kept from believing what other people do not believe, even if-and, perhaps, especially when - these others are their parents or educational and religious mentors. Thus, if we are not "to strangle the free mind at its source," the state's parens patriae duty must "cut[] against the differential regulation of public and private schools." ${ }^{80}$ All children are entitled to an education that is, in the fullest sense, public: that transports them beyond familiar boundaries; that provides a check on the narcissism of their guardians, both public and private; that burdens them with the necessity of moral judgment; and that, finally, makes them truly free, free to stand and free to fall. A public education is the portal by which children find a place or places on "the great sphere" that is their world and legacy. ${ }^{81}$ It is their means of escape from or 
free commitment to the social group in which they were born. It is their best guarantee of an open future. ${ }^{82}$

On this basis, the courts should refuse to allow parents to opt out of statemandated educational requirements they consider morally objectionable. On this basis, too, the courts should not allow parents to make the public school classroom a forum for their personal religious agenda. Yet if the classroom really is, as the Supreme Court has said, "peculiarly the "marketplace of ideas," the voices of religious children must be allowed to be heard, too. ${ }^{83}$ The educational market is a poorer place when school officials cleanse the classroom of religious references or deny children freedom of religious expression. To this end, the study of religion should be a regular part of a common curriculum. The public school classroom at every level should be a forum where students are exposed to diverse viewpoints, secular and religious. The idea that students benefit from exposure to otherness makes sense only if this benefit flows in all directions.

A truly public education may well divide child from parent. We should be entirely forthright and unapologetic about this. The state as educator is no ideologically neutral actor. ${ }^{84}$ The philosophical foundations supporting a public education are the liberal biases of our nation's intellectual forebearers, biases in favor of a nonauthoritarian approach to truth, of free argument and debate - what Thomas Jefferson called truth's "natural weapons" - and of a healthy sense of human fallibility. ${ }^{85}$ The open world of public schooling should be a place where children use these "weapons" to think about values, whether those values belong to parent or state, or to the "omnivorous peerculture," or to the cultural oligarchs of the marketplace and the media. ${ }^{86}$ We should admit as well that these biases will be more compatible with the beliefs of some religious groups than others. ${ }^{87}$ Still, it would be a misrepresentation of trust principles to associate them with antireligiosity. Indeed, a commitment to the child's open future may be the best guarantee of a society with rich and robust religious traditions. Children are natural religious seekers. (Recently, there has been talk of a religious generation gap, or, perhaps better put, a reverse religious generation gap, with children choosing lives of faith, much to the concern, if not dismay, of their more secularminded parents. $)^{88}$ As young adults, some will choose new spiritual paths 
and some will choose to abandon religious ways altogether, but many, if not most, will find their faith in traditional places, arriving where they started and perhaps knowing the place for the first time. ${ }^{89}$ For religious freedom to flourish, however, these choices must be genuine ones, based on knowledge and experience gathered, as it were, out of a multitude of tongues. For the child's sake, for its own sake, the state that protects the freedom of adults to choose a religious or a nonreligious path must also ensure that the freedom of children to choose their path will not be taken from them. Like adults, children must be free to seek as well as to find a spiritual home.

The Constitution's guarantee of personal freedoms is meaningful only if we, as parents, accept the responsibilities from which parental authority arises, and the constitutional strength of parenting privileges should depend on our willingness to do so. The real question is whether parenting furthers the prospective independence of the child. No doubt, there are many ways to achieve this goal. Treating parental authority as a trust does not mean denying parents the opportunity, in the words of the political theorist William Galston, to introduce their children "to what they regard as vital sources of meaning and value." ${ }^{90}$ It does mean that parents may not deny their children the opportunity to be introduced to new sources of meaning and value; it does mean that parents may not as a matter of right refuse to share authority for the upbringing of their children. There is, after all, more than one form of unlimited government to which children are vulnerable, and Justice Stevens is certainly correct to caution that " $\mathrm{t}]$ he constitutional protection against arbitrary state interference with parental rights should not be extended to prevent the States from protecting children against the arbitrary exercise of parental authority that is not in fact motivated by an interest in the welfare of the child." ${ }^{91}$

The trust model of parent-child relations heeds this admonitory note. In their consideration of parenting claims, courts ought not to treat the legal question as one of parental rights divorced from parental duties. ${ }^{92}$ Our legal traditions teach that parenthood is first and foremost a responsibility, a fiduciary duty owed equally to the child and the state. This time-honored tenet has great room for play in modern times. ${ }^{93}$ If allowed to, the form this responsibility takes will evolve, for our understanding of children's best 
interests - indeed, our very conception of childhood - evolves. Our duty to the child, however, will remain unchanged.

Like a doctrinal will-o'-the-wisp, the fundamental right to parent continues to beckon constitutional travelers. It is a pursuit driven more by psychology than law. The rhetoric of parental rights speaks to a yearning for control, for possession of something that is "mine." ${ }^{94}$ It evokes some Edenic time when parents, by right, could tell the state to mind its own business. It evokes some Edenic place where parents, by right, could command obedience from their children. But there never was such a time and place, certainly not in the law. In Meyer, the attorney Arthur Mullen stood before the Supreme Court to denounce the power of the state "to take the child from the parent." No state, Mullen argued, should "prescribe the mental bill of fare" the child will follow. ${ }^{95}$ His argument supposes that by legal tradition the child is the parent's to begin with, that the parent can prescribe the child's mental bill of fare. To the contrary, trust principles of parenting testify to the "moral fact that a person belongs to himself and not to others nor to society as a whole." 96

Though John Milton protested prepublication censorship, Milton’s God was less troubled by restrictions on the spectrum of available knowledge. When God's children disobey his sole commandment-a commandment, interestingly enough, that would deny Adam and Eve the knowledge of good and evil-they are cast out of their childhood home and sentenced to death for their disobedience. In Milton's telling, their fall, it turns out, is a fortunate one, their disobedience a prerequisite to "[a] Paradise within ..., happier far." ${ }^{\prime 7}$ The law of parent-child relations has long embodied a similar belief that education (a "leading away from") is the path away from childhood and toward intellectual and moral enfranchisement. Unless children are to live under "a perpetual childhood of prescription," unless we are to deny them the pursuit of happiness, perhaps in the fond hope of providing happiness, they must be exposed to the dust and heat of the race, intellectually, morally, spiritually. ${ }^{98}$

With all its attendant joys, parenting is a somber task, for it entails, in a profound and poignant way, the loss of the child. It is the parent's task-it 
is a political as well as a personal obligation - to enable each child to form his or her own self-image rather than merely to conform to some parental likeness. If we could, we might shield our children from the sufferings that accompany individuation. If we could, we might shield ourselves from the pain that accompanies the child's separation from our hands. Is it any wonder that we would want to transform the sacred trust of parenthood into a sacred right? But such a right comes at too great a cost. When Adam and Eve leave Paradise, as Milton recounts the story, they shed some natural tears, but "the World was all before them," as it should be for all children as they enter on the path to adulthood. 


\section{Chapter 1. Sacred Trust or Sacred Right?}

Epigraph. John Milton, Paradise Lost, in John Milton: Complete Poems and Major Prose, ed. Merritt Y. Hughes (Indianapolis: Odyssey Press, 1957) (1667) 469 (XII, 645-49).

1. The Etna, 8 F. Cas. $80_{3}, 80_{4}$ (D. Me. 1838).

2. 8 F. Cas. at 804 .

3. 8 F. Cas. at 806 ; see also 8 F. Cas. at 804.8 F. Cas. at 804.8 F. Cas. at 807 .

4. Cf. Joel Prentiss Bishop, Commentaries on the Law of Marriage and Divorce (Boston: Little, Brown, 1852) 515 ( $\$ 632$ ) ("At common law the father is, in some sense, the guardian of his children, though in precisely what sense, the books do not seem perfectly to agree.") (footnote omitted). In referring to a right to parent, I do not mean the right to bear or beget a child. See Eisenstadt v. Baird, 405 U.S. 438, 453 (1972) (recognizing "the right of the individual, married or single, to be free from unwarranted governmental intrusion into matters so fundamentally affecting a person as the decision whether to bear or beget a child").

5. United States v. Bainbridge, 24 F. Cas. 946, 949 (C.C.D. Mass. 1816) (emphasis added). Christopher G. Tiedeman, A Treatise on the Limitations of Police Power in the United States (St. Louis: F. H. Thomas Law, 1886) 554; see also Tiedeman, The Limitations of Police Power, 552: "By the abolition of the family relation as a political institution, the child, whatever may be his age, acquires the same claim to liberty of action as the adult, viz.: the right to the largest liberty that is consistent with the enjoyment of a like liberty on the part of others; and he is only subject to restraint, so far as such restraint is necessary for the promotion of the general welfare or beneficial as a means of protection to himself. The parent has no natural vested right to the control of his child" (emphasis added). 
6. Lewis Hochheimer, The Law Relating to the Custody of Infants, 3d ed. (Baltimore: Harold Scrimger, 1899) 22 (\$22).

7. Uniformity is hardly to be expected from "[t]he American federal system in which each state had jurisdiction over domestic relations," a system which "produced a range of custody and other family laws." Michael Grossberg, Comment, "Who Determines Children’s Best Interests?" L. \& Hist. Rev. 17 (1999): 309, 313-14.

8. Hochheimer, The Custody of Infants (1899) 22-23 (\$22); cf., e.g., Rollin C. Hurd, A Treatise on the Right of Personal Liberty and on the Writ of Habeas Corpus, 2d ed. (Albany: W. C. Little, 1876) 461 ("In controversies between parents for the custody of their legitimate children, the right of the father is held to be paramount to that of the mother; but the welfare of the child and not the technical legal right is the criterion by which to determine to whom the custody of the child shall be awarded"); James Schouler, A Treatise on the Law of the Domestic Relations, 2d ed. (Boston: Little, Brown, 1874) $365(\$ 339)$ ("The cardinal principle relative to such matters is to regard the benefit of the infant; to make the welfare of the children paramount to the claims of either parent. ... [J]udicial precedents, judicial dicta, and legislative enactments all lead to one and the same irresistible conclusion. The primary object of the American decisions is then to secure the welfare of the child, and not the special claims of one or the other parent") (footnote omitted); English v. English, 32 N.J. Eq. 738, 742-43 (N.J. Err. \& App. 1880) ("In considering the grounds which should have weight in deciding controversies of this character, while the rights of parents will not be disregarded or their interests overlooked, the court will not be controlled in its decision by the strict rights of either party, but will determine the question of custody mainly upon considerations of advantage to the infant; the cardinal rule of action governing the court being regard to the benefits of the minor, holding its welfare superior to the claims of either parent"); cf. also "Developments in the Law: The Constitution and the Family," Harv. L. Rev. 93 (1980): 1156, 1223 ("[Nineteenth-century custody courts] often held that the presumption of parental custody was based upon the extent to which the parent successfully served the state's interest in promoting the child's welfare, rather than upon any inherent right of the parent. Most late nineteenth century courts thus acknowledged that the child's welfare, not the parent's legal right, was the determinative factor in private custody decisions under the parens patriae power") (footnotes omitted).

9. James Kent, 2 Commentaries on American Law, ed. O. W. Holmes Jr., 12th ed. (Boston: Little, Brown, 1873) 252 (emphasis added). Kent, 2 Commentaries, 227. Joseph Story, 2 Commentaries on Equity Jurisprudence (Boston: Hilliard, Gray, 1836) 574-76 ( \$ \$ 1341-43) ("For, though in general parents are entrusted with the custody of the persons and the education of their children; yet this is done upon the natural presumption, that the children will be properly taken care of, and brought up with a due education in literature, and morals, and religion; and 
that they will be treated with kindness and affection. But whenever this presumption is removed . . in every such case, the Court of Chancery will interfere, and deprive him of the custody of his children, and appoint a suitable person to act as guardian, and to take care of them, and to superintend their education"); see also Story, 2 Equity Jurisprudence, 577 ( $(1345)$ ("Why is not the conduct of the father to be considered a trust, as well as the conduct of the person appointed as guardian?"). Hochheimer, The Law Relating to the Custody of Infants (Baltimore: John Murphy, 1887) 42 (\$10) ("[T]he general drift of opinion [in the American cases] is in the direction of treating the idea of trust as the controlling principle in all controversies in relation to such custody. As the trust which is implied in the guardianship of an infant calls into requisition the exercise of moral qualities, the tenderest and most sacred impulses of our nature, - love, affection, self-sacrificeand as there is no fixed standard by which the quality of these can be gauged or their operation determined, it follows, in the very nature of things, that any system of fixed, inflexible rules to be applied in the disposing of infants would lead to gross injustice and incalculable evil"). Hochheimer, The Custody of Infants (1899), $4(\$ 4)$. Tiedeman, The Limitations of Police Power, 552-53; cf. Ernst Freund, The Police Power: Public Policy and Constitutional Rights (Chicago: Callaghan, 1904) 248 ( $\$ 260$ ) ("Our constitutions are silent upon family rights and relations, and we should have to regard the parental power not only as a natural right, but as a natural right above the power of the state, to declare its legislative restraint to be unconstitutional. ... There is indeed a tendency to treat this right altogether as a power in trust, which may not only be checked in the case of manifest abuse, but the exercise of which may be directed by such rules as the legislature may establish as best calculated to promote the welfare of the child").

10. See, e.g., People ex rel. Brooks v. Brooks, 35 Barb. 85, 87 (N.Y. 1861). For a discussion of the American cases, see Hurd, Habeas Corpus, 472-521. On the right of guardianship as a trust in early English cases, see Kerry O'Halloran, The Welfare of the Child: The Principle and the Law (Brookfield, Vermont: Ashgate, 1999) 7-35; Sarah Abramowicz, Note, "English Child Custody Law, 1660-1839: The Origins of Judicial Intervention in Paternal Custody," Colum. L. Rev. 99 (1999): 1344, 1353-55; cf. Eyre v. Shaftesbury, 24 Eng. Rep. 659, 660 (Ch. 1722) ("The father by the statute has a right to dispose of the guardianship of his child until twenty-one, and having done so here, it will be binding, unless some misbehaviour be shewn in the guardian, in which case it being a matter of trust, this court has a superintendency over it") (citation omitted).

11. Brooks v. Brooks, 35 Barb. at 87-88; cf., e.g., Lippincott v. Lippincott, 128 A. 254 , 255 (N.J. Err. \& App. 1925) ("Manifestly, the touchstone of our jurisprudence in matters dealing with the custody and control of infants is the welfare and happiness of the infant, and not the filial affections naturally arising from parental or family relationship. Thus, it has been quite generally held that even the natural 
right of the father to the custody of his child cannot be treated as an absolute property right, but rather as a trust reposed in the father by the state, as parens patriae for the welfare of the infant") (citations omitted).

12. The Etna, 8 F. Cas. at 804 .

13. William Blackstone, 1 Commentaries on the Laws of England (Oxford: Clarendon Press, 1765) 435; cf. Francis Hutcheson, A System of Moral Philosophy (1755) 192 ("This grand end of the parental power shows that it includes few of those rights contained in the patria potestas of the Romans. The child is a rational agent, with rights valid against the parents; though they are the natural tutors or curators, and have a right to direct the actions, and manage the goods of the child, for its benefit, during its want of proper knowledge"). John Locke, Two Treatises of Government, ed. Peter Laslett (New York: Cambridge University Press, 1960) II, VI, \$ 68.

14. See Steven G. Calabresi and Sarah E. Agudo, "Individual Rights Under State Constitutions When the Fourteenth Amendment Was Ratified in 1868: What Rights Are Deeply Rooted in American History and Tradition?” Tex. L. Rev. 87 (2008): 7, 108-11. In 1868, thirty-six out of thirty-seven states made the provision of public education a constitutional duty. Calabresi and Agudo conclude that "[a] right to a public-school education is thus arguably deeply rooted in American history and tradition and is implicit in the concept of ordered liberty." "Individual Rights Under State Constitutions," 108. See also Allen W. Hubsch, "The Emerging Right to Education Under State Constitutional Law," Temple L. Rev. 65 (1992): 1325. On state constitutions and positive rights, see Burt Neuborne, "Foreword: State Constitutions and the Evolution of Positive Rights," Rutgers L.J. 20 (1989): 881; cf. Jonathan Feldman, "Separation of Powers and Judicial Review of Positive Rights Claims: The Role of State Courts in an Era of Positive Government," Rutgers L.J. 24 (1993): 1057. States have also protected unenumerated rights under various constitutional provisions, see Calabresi and Agudo, "Individual Rights Under State Constitutions," 88-89; cf. Suzanna Sherry, "Natural Law in the States," U. Cin. L. Rev. 61 (1992): 171, including a fundamental right to parent, see, e.g., In re J.P., 648 P.2d 1364 (Utah 1982).

15. Hochheimer, The Custody of Infants (1899), 22 ( $\$ 22$ ) (footnote omitted); cf.

Bishop, Commentaries, $526(\$ 643)$ ("[T]he children, though younger in years, have themselves an interest even more sacred than their parents, and more deserving of protection. Indeed, no parent has properly an interest in the mere custody of a child").

16. Hochheimer, The Custody of Infants (1887), 41 ( $\$ 10)$.

17. Martha Fineman, "Dominant Discourse, Professional Language, and Legal Change in Child Custody Decisionmaking," Harv. L. Rev. 101 (1988): 727, 737; cf., e.g., Elizabeth S. Scott and Robert E. Scott, "Parents as Fiduciaries," Va. L. Rev. 81 (1995): 2401, 2406 ("Before the twentieth century, the combined status of biological parenthood and marriage signified a legal authority [over children] of 
almost limitless scope"); Janet L. Dolgin, “Just a Gene: Judicial Assumptions About Parenthood," UCLA L. Rev. 40 (1993): 637 n.29 (Before the Industrial Revolution, "under common law, fathers had an absolute right to the custody of their children. The common law view [of paternal rights] represented a modification of Roman law under which children were fully defined as paternal property") (citation omitted).

18. See, e.g., State v. Clottu, 33 Ind. 409, 411 (Ind. 1870) ("The duties and authority pertaining to the relation of parent and child have their foundations in nature, it is true. Nevertheless, all civilized governments have regarded this relation as falling within the legitimate scope of legislative control. Except in countries which lie in barbarism, the authority of the parent over the child is nowhere left absolutely without municipal definition and regulation"); People ex rel. Barry v. Mercein, 3 Hill 399 (N.Y. Sup. 1842) ("Those countries in which the father has a general power to dispose of his children, have always been considered barbarous. Our own law never has allowed the exercise of such power except for some specific and temporary purpose, such as apprenticeship during the father's life, or guardianship after his death"); cf. Joel Prentiss Bishop, 2 New Commentaries on Marriage, Divorce, and Separation (Chicago: T. H. Flood, 1891) 454 (\$1163) ("Under laws which have prevailed in some ages and countries, rendering the child a sort of chattel in the hands of its father, who could sell or kill it, the paternal right to its custody was necessarily inflexible. But this old barbarity has gradually given way until the modern civilization concedes to the child the same attributes which it acknowledges in the father") (footnote omitted).

19. Story, 2 Equity Jurisprudence, 578 ( $\$ 1347)$.

20. In discussing American case law, I use "common law" to refer to judge-made law, whether formally derived at law or in equity. On the early embrace of equitable principles by American courts of law, see, for example, Hurd, Habeas Corpus, 465 ("[T] he equitable doctrine maintained in [Rex v. Delaval, 3 Burr. 1434, 1436 (K.B. ${ }_{1763)}$ ] has been commonly practiced in this country and may now be considered as thoroughly incorporated in the American common law"); Kent, 2 Commentaries, 231 ("The father may obtain the custody of his children by the writ of habeas corpus, when they are improperly detained from him; but the courts, both of law and equity, will investigate the circumstances, and act according to sound discretion”) (footnote omitted); cf. People ex rel. Barry v. Mercein, 8 Paige Ch. 47, 55-56 (N.Y. Ch. 1839) ("[T]he power of the chancellor to issue a habeas corpus is not derived solely from the statute, but is also an inherent power in the court, derived from the common law... The court of chancery, upon such writ [of habeas corpus], will exercise its discretion, in disposing of the custody of the infant, upon the same principles which regulate the exercise of a similar discretion by other courts and officers who are authorized to allow the writ in similar cases"); cf. Stanley N. Katz, "The Politics of Law in Colonial America: Controversies over Chancery 
Courts and Equity Law in the Eighteenth Century," in Law in American History, eds. Donald Fleming and Bernard Bailyn (Boston: Little, Brown, 1971) 257. Katz charts the emergence of a "distinctively colonial equity law." Where separate colonial chancery courts were not established, "equity law and procedure were amalgamated into the courts of the common law or also, as in New England, into the legislatures." "The Politics of Law in Colonial America," 263.

It is not always clear what time period is meant by reference to "common law" or "early common law." For instance, R. Collin Mangrum begins his discussion of child custody cases by describing the "near absolute power of the father over his children" at "early common law." He refers to feudalism and the patriarchal orientation of Christianity as firmly establishing property-oriented custody principles. He cites Blackstone to show that paternal power "was akin to the Roman rule of patria potestas." Yet he also notes that Blackstone himself depicted the common law as "much more moderate" than the Roman code, and Mangrum goes on to discuss how eighteenth-century equitable modifications mitigated "the harshness of the common law rule." So what common law did the American colonies receive? Mangrum notes that " $[\mathrm{t}]$ he feudal structure out of which the propertyoriented rule of paternal preference arose was never part of our tradition. The English common law was 'received' by the newly-formed states after the Revolution only insofar as it fit the circumstances of the respective states." See "Exclusive Reliance on Best Interest May be Unconstitutional: Religion as a Factor in Child Custody Cases," Creighton L. Rev. 15 (1981): 25, 31-44.

On local custom and the adaptability of American common law, see Ellen Holmes Pearson, Remaking Custom: Law and Identity in the Early American Republic (Charlottesville: University of Virginia Press, 2011) 11-30.

21. Blackstone, 1 Commentaries, 440-41; cf. Kent, 2 Commentaries, 231 ("The father ... has the benefit of his children's labor while they live with him, and are maintained by him; and this is no more than he is entitled to from his apprentices or servants") (footnote omitted).

22. Kent, 2 Commentaries, 231; see also Hochheimer, The Custody of Infants (1899), $54-59\left(\int S 44-46\right)$.

23. In re Gregg, 5 New York Legal Observer 265, 267 (N.Y. Super. 1847).

24. Legate v. Legate, 28 S.W. 281, 282 (Tex. 1894).

25. Kent, 2 Commentaries, 225-26; cf. Kelley v. Davis, 6 Am. Rep. 499, 502 (N.H. 1870) ("[T] he common law considered moral duties of this nature as better left in their performance to the impulses of nature") (internal quotation marks omitted).

26. See, e.g., Hochheimer, The Custody of Infants (1899), 36-40 (\$S 34-38).

27. In re Gregg, 5 New York Legal Observer at 267. Mercein v. People ex rel. Barry, 25 Wend. 64, 103 (N.Y. 1840). United States v. Green, 25 F. Cas. 30,32 (C.C.R.I. 1824). Ex parte Crouse, 4 Whart. 9, 11 (Pa. 1839); cf. In re Ferrier's Petition, 103 Ill. 
$367,372(1882)$ ("[The court's] jurisdiction extends to the care and person of the infant, so far as is necessary for his protection and education, and upon this ground that court interferes with the ordinary rights of parents in regard to the custody and care of their children") (emphasis added).

28. Legate v. Legate, $28 \mathrm{~S}$.W. at 282.

29. See, e.g., Swoap v. Superior Court, 516 P.2d 840, 849 (Cal. 1973) ("It is thus abundantly clear that a long tradition of law, not to mention a measureless history of societal customs, has singled out adult children to bear the burden of supporting their poor parents").

30. Gerald Gunther, "Foreword: In Search of Evolving Doctrine on a Changing Court: A Model for a Newer Equal Protection," Harv. L. Rev. 86 (1972) 1, 8 (internal quotation marks omitted). But see Adarand Constructors, Inc. v. Pena, 515 U.S. 200, 237 (1995) ("[W]e wish to dispel the notion that strict scrutiny is 'strict in theory, but fatal in fact."); see also Adam Winkler, "Fatal in Theory and Strict in Fact: An Empirical Analysis of Strict Scrutiny in the Federal Courts," Vand. L. Rev. 59 (2006): 793

31. See Slaughter-House Cases, 83 U.S. 36, 80 (1872) (The protection of due process "has been in the Constitution since the adoption of the fifth amendment, as a restraint upon the Federal power. It is also to be found in some form of expression in the constitutions of nearly all the States, as a restraint upon the power of the States. This law then, has practically been the same as it now is during the existence of the government, except so far as the present amendment may place the restraining power over the States in this matter in the hands of the Federal government"); see also Calabresi and Agudo, "Individual Rights Under State Constitutions," 66 (noting that, in 1868, thirty out of thirty-seven states "had clauses in their state constitutions that explicitly prohibited the deprivation of life, liberty, or property without due process of law or by the law of the land").

32. Michael H. v. Gerald D., 491 U.S. 110, 122 (1989) (quoting Snyder v. Massachusetts, 291 U.S. 97, 105 [1934]); see also Griswold v. Connecticut, 381 U.S. 479, 501 (1965) (Harlan, J., concurring in judgment) ("Judicial self-restraint will . . . be achieved in this area, as in other constitutional areas, only by continual insistence upon respect for the teachings of history, solid recognition of the basic values that underlie our society, and wise appreciation of the great roles that the doctrines of federalism and separation of powers have played in establishing and preserving American freedoms"). Palko v. Connecticut, 302 U.S. 319, 325 (1937).

33. Troxel v. Granville, 530 U.S. 57, 64, 66 (2000).

34. The work of David D. Meyer is especially helpful on this point. Meyer argues that, "notwithstanding the [Court's] broad language exalting the 'fundamental' nature of family privacy rights, the Court in truth has applied something less than strict scrutiny in their defense." "What Constitutional Law Can Learn from the 
ALI Principles of Family Dissolution," BYU L. Rev. 2001 (2001): 1075, 1090; see also David D. Meyer, "The Paradox of Family Privacy," Vand. L. Rev. 53 (2000): 527, 536-47 (reviewing cases); Lee E. Teitelbaum, "Family History and Family Law," Wis. L. Rev. 1985 (1985): 1135, 1157 ("What is most striking about these cases [where the Court has drawn a line against state regulation of parent-child relations], however, is not the strong language they employ in support of values of pluralism and deference to parental authority but the narrowness of the exceptions they recognize to state authority in respect of education"); cf. James E. Fleming and Linda C. McClain, Ordered Liberty: Rights, Responsibilities, and Virtues (Cambridge: Harvard University Press, 2013) 237-72 (arguing that the Supreme Court's due process jurisprudence has not relied on strict scrutiny of fundamental rights). The exceptionalism of family law-specifically, its (sometimes) exemption from strict scrutiny - is also evident in the equal protection context. See, e.g., David D. Meyer, "Palmore Comes of Age: The Place of Race in the Placement of Children," U. Fla. J. L. \& Pub Pol'y 18 (2007): 183; Elizabeth Bartholet, "Where Do Black Children Belong?: The Politics of Race Matching in Adoption," U. Pa. L. Rev. 139 (1991): 1163 .

35. Troxel v. Granville, 530 U.S. at 92 (Scalia, J., dissenting) ("Only three holdings of this Court rest in whole or in part upon a substantive constitutional right of parents to direct the upbringing of their children - two of them from an era rich in substantive due process holdings that have since been repudiated") (footnote omitted).

36. For example, as Paula Abrams has pointed out, the parent petitioners in Bolling v. Sharpe, 347 U.S. 497 (1954) - this is the companion case to Brown v. Board of Education, 347 U.S. 483 (1954) - asked the court to hold that segregated public schooling violates the fundamental due process right of parents to direct the education of their children. See Cross Purposes: Pierce v. Society of Sisters and the Struggle over Compulsory Public Education (Ann Arbor: University of Michigan Press, 2009) 217. Relying on Meyer v. Nebraska, 262 U.S. 390 (1923), Pierce v. Society of Sisters of the Holy Names of Jesus and Mary, 268 U.S. 510 (1925), and Farrington v. Tokushige, 273 U.S. 284 (1927), the parents claimed that "[t]his Court has recognized that this right includes liberty of choice of parents and their children in the selection of the type of education which parents and their children think important." Brief of Petitioners on Reargument, Spottswood Thomas Bolling, et al., at 51, Bolling v. Sharpe, 347 U.S. 497 (1954).

37. Meyer v. Nebraska, 262 U.S. 390 (1923). Pierce v. Society of the Sisters of the Holy Names of Jesus and Mary, 268 U.S. 510 (1925). In Pierce, the appellee Society of Sisters did address parental rights, see Brief of Appellee, in Oregon School Cases: Complete Record (Baltimore: Belvedere Press, 1925) 321-330, and before the Court attorney William Guthrie briefly argued the position "that the right of parents to 
send their children to private schools of their own choice is a fundamental, natural and sacred right," Transcript of Oral Argument, in Oregon School Cases, 653.

38. Meyer, 262 U.S. at 402; cf. Runyon v. McCrary, 427 U.S. 160, 178 (1976); Wisconsin v. Yoder, 406 U.S. 205, 234-35 (1972); Bd. of Educ. v. Allen, 392 U.S. 236, 247 (1968).

39. Poe v. Ullman, 367 U.S. 497, 543 (1961) (Harlan, J., dissenting).

40. Justice Thomas's dissent in Brown v. Entertainment Merchants Association, 131 S.Ct. 2729, 2758-59 (2011), suggests, unintentionally one presumes, that traditionally the state could go very far indeed: "In the decades leading up to and following the Revolution, the conception of the child's mind evolved but the duty and authority of parents remained. Indeed, society paid closer attention to potential influences on children than before. By weakening earlier forms of patriarchal authority, the Revolution enhanced the importance of childrearing and education in ensuring social stability. Teachers and schools came under scrutiny, and children's reading material was carefully supervised. Laws reflected these concerns and often supported parental authority with the coercive power of the state" (emphasis added) (citation and internal quotation marks omitted). Thomas cites Benjamin Rush, among other authorities, to support the contention that, at the time of the founding generation, parents had total control over their children's lives. It would be more accurate to say that what Rush supported was total state control over the lives of its future citizens. See Benjamin Rush, "Thoughts upon the Mode of Education Proper in a Republic," in Essays on Education in the Early Republic, ed. Frederick Rudolph (Cambridge: Harvard University Press, 1965) 11 ("From the observations that have been made it is plain, that I consider it possible to convert men into republican machines. This must be done if we expect them to perform their parts properly, in the great machine of the government of the state"); see also Rush, "Thoughts upon the Mode of Education," 14 ("Let our pupil be taught that he does not belong to himself, but that he is public property. Let him be taught to love his family, but let him be taught at the same time that he must forsake and even forget them when the welfare of his country requires it"). Among other measures meant to produce republican uniformity of character, Rush urged the creation of a federal university "where the youth of all the states may be melted (as it were) into one mass of citizens." 1 Letters of Benjamin Rush, ed. Lyman H. Butterfield (Princeton: Princeton University Press, 1951) 388.

41. Meyer v. State, 187 N.W. 100, 104 (Neb. 1922) (Letton, J., dissenting); cf. Berea College v. Kentucky, 211 U.S. 45, 67 (1908) (Harlan, J., dissenting) ("The capacity to impart instruction to others is given by the Almighty for beneficent purposes and its use may not be forbidden or interfered with by Government, - certainly not, unless such instruction is, in its nature, harmful to the public morals or imperils the public safety"). 
42. Pierce, 268 U.S. at 534 .

43. Yoder, 406 U.S. at 213; cf. State v. Counort, 124 P. 910, 911-12 (Wash. 1912) (rejecting homeschooling claim) ("We do not think that the giving of instruction by a parent to a child, conceding the competency of the parent to fully instruct the child in all that is taught in the public schools, is within the meaning of the law 'to attend a private school.' Such a requirement means more than home instruction. It means the same character of school as the public school, a regular, organized and existing institution, making a business of instructing children of school age in the required studies and for the full time required by the laws of this state").

44. See, e.g., Kenneth B. O'Brien Jr., "Education, Americanization, and the Supreme Court: The 1920's," American Quarterly 13 (1961): 161, 171 ("It is difficult to overestimate the import [of these cases]"); see also, e.g., Stephen Arons, "The Separation of School and State: Pierce Reconsidered," Harv. Educ. Rev. 46 (1976): 76; cf. Stephen L. Carter, "Parents, Religion, and Schools: Reflections on Pierce, 70 Years Later," Seton Hall L. Rev. 27 (1997): 1194.

Even Pope Pius XI lavished praise on Pierce, writing in a 1929 encyclical letter on education: "This incontestable right of the family has at various times been recognized by nations anxious to respect the natural law in their civil enactments. Thus, to give one recent example, the Supreme Court of the United States of America, in a decision on an important controversy, declared that it is not in the competence of the State to fix any uniform standard of education by forcing children to receive instruction exclusively in public schools, and it bases its decision on the natural law: the child is not the mere creature of the State; those who nurture him and direct his destiny have the right coupled with the high duty, to educate him and prepare him for the fulfillment of his obligations." Divini Illius Magistri ("On the Christian Education of Youth") (Dec. 31, 1929), 37, at http:// www.vatican.va/holy_father/pius_xi/encyclicals/documents/hf_p-xi_enc_31121929 _divini-illiusmagistri_en.html, cited in David R. Upham, "Pierce v. Society of Sisters, Natural Law, and the Pope's Extraordinary-But Undeserved-Praise of the American Republic" [Draft], 4, at http://papers.ssrn.com/sol3/papers.cfm?abstract _id=2018396; see also Christopher Wolfe, "The Supreme Court and Catholic Social Thought," Am. J. Juris. 29 (1984): 45, 50-51.

45. Yoder, 406 U.S. at 239 (White, J., concurring).

46. Consider the dissenting opinion of Judge (and later Supreme Court Justice) Peckham, who would author Lochner, in People v. Budd, 117 N.Y. 1, 47 (1889) (Peckham, J., dissenting): "I have spoken thus somewhat at length upon this subject ... for the purpose of showing that, because the rule [regarding common carriers] is correctly stated in those cases, no reason exists in such fact for the extension of the principle of that rule to other cases, and, by doing so, go back to the seventeenth or eighteenth century ideas of paternal government, and thereby 
wholly ignore the later and, as I firmly believe, the more correct ideas which an increase of civilization and a fuller knowledge of the fundamental laws of political economy, and a truer conception of the proper functions of government have given us at the present day. Rights which we would now regard as secured to us by our bill of rights against all assaults, from whatever quarter, were in those days regarded as the proper subjects of legislative interference and suppression. The fact that certain rules of the common law have come down to us unimpaired, although based upon a view of the relations of government to the people which obtained in the seventeenth century, should certainly furnish no reason for extending those rules to cases which, but for such extension, would be regarded as clearly within the protection of the constitutional limitations contained in our bill of rights."

47. Both liberals and conservatives have sought to distance Meyer and Pierce from Lochner (or, at least, from what David E. Bernstein calls the "mythical, evil Lochner" of modern constitutional law). See Rehabilitating Lochner: Defending Individual Rights Against Progressive Reform (Chicago: University of Chicago Press, 2011) 108-24. As Bernstein argues, this distancing is more strategically prudent than historically sound. "Justice Peckham's enunciation of an expansive liberty-protective interpretation of the [Due Process Clause] in Lochner (and Allgeyer) begot Justice McReynolds' even more expansive opinion in Meyer, which continues to serve as the constitutional foundation of various Fourteenth Amendment rights protected by the Supreme Court." Bernstein, Rehabilitating Lochner, 124.

48. Employment Div., Dept. of Human Res. of Oregon v. Smith, 494 U.S. 872 (1990).

49. Yoder, 406 U.S. at 233 (1972).

50. Smith, 494 U.S. at 881 . Yoder, 406 U.S. at 234.

51. Smith, 494 U.S. at 879 (quoting Reynolds v. United States, 98 U.S. 145, 166-67 [1878]).

52. The Yoder Court suggested that its holding might be limited to "a free exercise claim of the nature revealed by this record." See 406 U.S. at 233.

53. Stephen Gilles, "On Educating Children: A Parentalist Manifesto," U. Chi. L. Rev. 63 (1996): 937.

54. See Santosky v. Kramer, 455 U.S. 745 (1982).

55. Meyer, "Paradox of Family Privacy," 527.

56. 530 U.S. 57 (2000).

57. Brown v. Hot, Sexy and Safer Prods., 68 F.3d 525, 533 (1st Cir. 1995).

58. Cf. Bertrand Fry, "Breeding Constitutional Doctrine: The Provenance and Progeny of the 'Hybrid Situation' in Current Free Exercise Jurisprudence,” Tex. L. Rev. 71 (1993): 833, 62 ("About the lack of coherent protection there can be no doubt. In different areas of law, the hybrid situation doctrine generates different effects"). 
59. Cf. John P. Forren, "Revisiting Four Popular Myths about the Peyote Case," U. Pa. J. Const. L. 8 (2006): 209, 219 ("Smith left lower court judges ... with extraordinary amounts of doctrinal leeway to decide precisely what controlling First Amendment precedents now required them to do").

6o. See http://www.parentalrights.org/index.asp?Type=B_BASIC\&SEC $=\{$ DE675888$\left.\mathrm{E} 60 \mathrm{~A}-4219-8 \mathrm{~A} 5 \mathrm{E}-000083244 \mathrm{D}_{13}\right\} \& \mathrm{DE}=$. The justification of the amendment rests on twin pillars of concern for the uncertain status of parental rights. First, supporters worry that the federal courts have been less than strident in their defense of the right to parent. Second, supporters worry about erosion of parental authority should the United States ratify the United Nations Convention on the Rights of the Child. The amendment reads in its entirety: "Section 1: The liberty of parents to direct the upbringing and education of their children is a fundamental right. Section 2: Neither the United States nor any State shall infringe upon this right without demonstrating that its governmental interest as applied to the person is of the highest order and not otherwise served. Section 3: No treaty may be adopted nor shall any source of international law be employed to supersede, modify, interpret, or apply to the rights guaranteed by this article."

Since 1990, critics of Smith have also sought a statutory return to the heightened review of free exercise claims. In 1993, Congress passed the Religious Freedom Restoration Act (RFRA), which reinstated Yoder's strict scrutiny standard for any federal or state action that "substantially burden[s] a person's exercise of religion even if that burden results from a rule of general applicability." See 42 U.S.C. \$200obb-1(b) (1993) ("Government may substantially burden a person's exercise of religion only if it demonstrates that application of the burden to the person - (1) is in furtherance of a compelling governmental interest; and (2) is the least restrictive means of furthering that compelling governmental interest"). The federal RFRA was overturned insofar as it applied to the states. See City of Boerne v. Flores, 521 U.S. 507 (1997). But cf. Gonzales v. O Centro Espírita Beneficente Uniao do Vegetal, 546 U.S. 418 (2006) (upholding under RFRA decision enjoining federal government from enforcing Controlled Substances Act to ban use of hoasca, a tea with hallucinogenic properties, in religious ceremonies). The downfall of RFRA as applied to the states led to the passage of the Religious Land Use and Institutionalized Persons Act (RLUIPA), Pub. L. No. 106-274, 114 Stat. 803 (2000) (codified at 42 U.S.C. $\iint 2000 c c$ [2000] (applying strict scrutiny to prisoner rights and discriminatory land use claims). A number of states have passed RFRAs of their own. See Christopher C. Lund, "Religious Liberty After Gonzales: A Look at State RFRAs," S.D. L. Rev. 55 (2010): 466, 466-67 n.7 \& 477 n.67 (citing and describing state statutes). The successful assertion of fundamental rights under state RFRA regimes has been modest at best. Lund, 479-96. It should also be noted that some states interpret their state constitutions to be more protective of religious liberty than the federal constitution. Lund, "Religious Liberty After Gonzales," 478 . 
61. Meyer, "What Constitutional Law Can Learn from the ALI Principles," 1090. Troxel v. Granville, 530 U.S. at 86 (Stevens, J., dissenting).

62. Cf. generally James G. Dwyer, The Relationship Rights of Children (New York: Cambridge University Press, 2006); Dwyer, "Parents' Religion and Children's Welfare: Debunking the Doctrine of Parents' Rights," Calif. L. Rev. 82 (1994): 1371.

63. Cf. Troxel v. Granville, 530 U.S. at 88 (Stevens, J., dissenting) “"A parent's rights with respect to her child have thus never been regarded as absolute, but rather are limited by the existence of an actual, developed relationship with a child, and are tied to the presence or absence of some embodiment of family. These limitations have arisen, not simply out of the definition of parenthood itself, but because of this Court's assumption that a parent's interests in a child must be balanced against the State's long-recognized interests as parens patriae and, critically, the child's own complementary interest in preserving relationships that serve her welfare and protection") (citations omitted).

64. Martha Minow, Making All the Difference: Inclusion, Exclusion, and American Law (Ithaca: Cornell University Press, 1990) 293; see also Making All the Difference, 383 ("Especially in struggles to secure greater respect for those ... who remained dependent after others had secured rights for autonomous action, rights provide a rhetoric for naming and scrutinizing both private and public power"). Indeed, as Minow observes, asserting rights is one way that people can "signal and strengthen their relation to a community." Making All the Difference, 294.

65. From fiduciary principles one might argue in favor of strong deference to parental choices. See, e.g., Elizabeth S. Scott and Robert E. Scott, "Parents as Fiduciaries," Va. L. Rev. (1995): 2401.

66. Cf., e.g., Mary Ann Glendon, Rights Talk: The Impoverishment of Social Discourse (New York: Free Press, 1991) 110; Moore v. City of East Cleveland, Ohio 431 U.S. 494, 544 (1997) (White, J., dissenting). On the rise and fall of the rights critique generated by Critical Legal Studies, see Robin West, Normative Jurisprudence: An Introduction (New York: Cambridge University Press, 2011) 107-76.

Soon after the Supreme Court's decision in Pierce, future justice Felix Frankfurter issued a similar warning about the illiberal use of due process in the service of liberalism: "For ourselves, we regard the cost of this power of the Supreme Court on the whole as greater than its gains. After all, the hysteria and chauvinism that forbade the teaching of German in Nebraska schools may subside, and with its subsidence bring repeal of the silly measure; the narrow margin by which the Oregon law was carried in 1922 may, with invigorated effort on the part of the liberal forces, result in its repeal, at least by a narrow margin. But when the Supreme Court strikes down legislation directed against trade unions, or enshrines the labor injunction into the Constitution, or denies to women in industry the meagre protection of minimum wage legislation, we are faced with action more far-reaching, because ever so much more durable and authoritative than even the 
most mischievous of repealable state legislation.... And here is ample warning to the liberal forces that the real battles of liberalism are not won in the Supreme Court. To a large extent the Supreme Court, under the guise of constitutional interpretation of words whose contents are derived from the disposition of the Justices, is the reflector of that impalpable but controlling thing, the general drift of public opinion. Only a persistent, positive translation of the liberal faith into the thoughts and acts of the community is the real reliance against the unabated temptation to straitjacket the human mind." See Felix Frankfurter, "Can the Supreme Court Guarantee Toleration?," New Republic, June 17, 1925, 85, 86-87.

67. Compare Frank I. Michelman on the role that a counter-ideology can play in constitutional law and theory. "The Supreme Court, 1985 Term - Foreword: Traces of Self-Government," Harv. L. Rev. 100 (1986) 4, 17-18: "The role is that of a counter-ideology, a normative political vision to set against the vision believed to have predominated in the thought of the framers and in the Constitution they framed. Such a visionary 'opposite,' if reasonably clear and coherent, may serve a number of heuristic and argumentative functions important to constitutional lawyers. Viewed as a rejected alternative, the 'opposite' can be used to clarify the assumptions and aims of the prevailing scheme. Viewed as a partially accepted or surviving competitor, it offers lawyers both a framework for interpretive debate and a premise for 'deviationist doctrine.' We can dispute constitutional issues, and innovate doctrinal futures, by debating the extent to which the 'opposite' survived and entered into the Constitution as a detectable, significant influence, fairly invocable in the work of interpretation."

68. Lehr v. Robertson, 463 U.S. 248,257 (1983); see also Caban v. Mohammed, 441 U.S. 380 (1979); Quilloin v. Walcott, 434 U.S. 246 (1978); Stanley v. Illinois, 405 U.S. 645 (1972); cf. Moore v. City of East Cleveland, 431 U.S. 494, 504-05 (1977). 69. Locke, Two Treatises, II, VI, $\$ 54$.

70. See generally David A. J. Richards, "The Individual, the Family, and the Constitution: A Jurisprudential Perspective," N.Y.U. L. Rev. 55 (1980): 1. Richards argues that "the hermeneutics of constitutional interpretation must explicate background concepts of liberal political theory because the meaning of constitutional rights is best explained in light of the theoretical perspective of the Founders and a reasonable elaboration of that perspective in contemporary circumstances." Richards, 7 n. 46 .

71. Kenneth Maddock, The Australian Aborigines: A Portrait of Their Society (Ringwood: Penguin, 1972) 193-94.

72. Caban v. Mohammed, 441 U.S. at 397 (Stewart, J., dissenting).

73. Jennifer Nedelsky, "Reconceiving Autonomy: Sources, Thoughts and Possibilities," Yale J.L. G Feminism 1 (1989): 7, 12; see also Elizabeth Bartholet, Nobody's Children: Abuse and Neglect, Foster Drift, and the Adoption Alternative (Boston: Beacon Press, 1999) 3 ("Children will be able to thrive in our society only if we 
begin to think of children born to other people, and to other racial groups, and to poor people, and to people who live elsewhere, as in some sense 'ours.").

74. William Shakespeare, A Midsummer Night's Dream, IV.1.19o-91. All references to Shakespeare are to The Complete Works of Shakespeare, ed. David Bevington (New York: Longman, 1997). The midsummer night's forest journey is a passage away from possessive pronouns. Consider the language of Egeus, Hermia's father, who, at the start of the play, seeks to dispose of his daughter as he sees fit: "Scornful Lysander! true, he hath my love/And what is mine my love shall render him. /And she is mine, and all my right of her/I do estate unto Demetrius." I.1.95-98; cf. Nedelsky, "Reconceiving Autonomy," 12 (The possessive pronoun evokes "the isolated, distancing symbol of property").

75. Locke, Two Treatises, II, VI, $\$ 149$. Does the state's authority to act for certain ends imply a duty to do so? Not as a matter of constitutional law doctrine. See DeShaney v. Winnebago Cnty. Dept. of Soc. Servs., 489 U.S. 189 (1989). But cf. Robin West, “Unenumerated Duties," U. Pa. J. Const. L. 9 (2006): 221.

76. Cf. generally, e.g., Suzanna Sherry, "Responsible Republicanism: Educating for Citizenship," U. Chi. L. Rev. 62 (1995): 131; Stanley Ingber, "Socialization, Indoctrination, or the 'Pall of Orthodoxy': Value Training in the Public Schools," U. Ill. L. Rev. 1987 (1987): 15 .

77. Pierce, 268 U.S. at 535 .

78. Barbara Bennett Woodhouse, "Who Owns the Child?: Meyer and Pierce and the Child as Property," Wm. E Mary L. Rev. 33 (1992): 995, 1001.

79. Bd. of Educ., Island Trees Union Free Sch. Dist. No 26 v. Pico, 457 U.S. 853 (1982); see also Griswold v. Connecticut, 381 U.S. at 482 ("[T] he State may not, consistently with the spirit of the First Amendment, contract the spectrum of available knowledge").

8o. West Virginia Bd. of Educ. v. Barnette, 319 U.S. 624, 637 (1943). Harry Brighouse, "School Vouchers, Separation of Church and State, and Personal Autonomy," in Moral and Political Education, eds. Stephen Macedo and Yael Tamir (New York: New York University Press, 2002) 244, 247.

81. See Bruce A. Ackerman, Social Justice in the Liberal State (New Haven: Yale University Press, 1980) 159 ("The entire educational system will, if you like, resemble a great sphere. Children land upon the sphere at different points, depending on their primary culture; the task is to help them explore the globe in a way that permits them to glimpse the deeper meanings of the dramas passing on around them. At the end of the journey, however, the now mature citizen has every right to locate himself at the very point from which he began - just as he may also strike out to discover an unoccupied portion of the sphere").

82. See Joel Feinberg, "The Child's Right to an Open Future," in Whose Child?: Children's Rights, Parental Authority, and State Power, eds. William Aiken and Hugh LaFollette (Totowa: Adams \& Co., 1980) 124-53. 
83. Keyishian v. Bd. of Regents of Univ. of State of N.Y., 385 U.S. 589, 683 (1967).

84. Cf. Stanley Ingber, Comment, "Religious Children and the Inevitable Compulsion of Public Schools," Case W. Res. L. Rev. 43 (1993): 773, 778-79 (“A value-free curriculum is clearly impossible.... [S]chools simply cannot attain value-neutral or balanced education. With only limited resources and time, they cannot possibly provide curricula that encompass the world's enormous mass of information and perspectives. Furthermore, subtle characteristics such as style and emphasis may undermine any substantive success in achieving balanced presentations. Even if these practical difficulties could be overcome, an insurmountable conceptual problem remains: Value neutrality itself has a value bias favoring the liberal philosophy embodied by the scientific method of inquiry") (footnote omitted).

85. Thomas Jefferson, "The Statute of Virginia for Religious Freedom" (1786), in The Virginia Statute for Religious Freedom: Its Evolution and Consequences in American History, eds. Merrill D. Peterson and Robert C. Vaughan (New York: Cambridge University Press, 1988) xvii.

86. The phrase "omnivorous peer-culture" belongs to Richard Hofstadter. See AntiIntellectualism in American Life (New York: Alfred A. Knopf, 1963) $3^{8} 3$.

87. Cf. Stephen Macedo, "The Constitution, Civic Virtue, and Civil Society: Social Capital as Substantive Morality," Fordham L. Rev. 69 (2001): 1573, 1593 ("The patterns of social life that support liberal democratic forms of civil flourishing embody definite rankings of competing human goods, which will be associated with some versions of religious truth and not others. In this sense, the project of promoting a healthy liberal democratic civil society is inevitably a deeply judgmental and non-neutral project"); William Galston, "Two Concepts of Liberalism," Ethics 105 (1995): 516, 526 ("[A]ny liberal argument that invokes autonomy as a general rule of public action in effect takes sides in the ongoing struggle between reason and faith, reflection and tradition. Autonomy-based arguments are bound to marginalize those individuals and groups who cannot conscientiously embrace [the principles of liberal autonomy]").

88. See Katherine Rosman, "Religion's Generation Gap," Wall Street Journal (March 2, 2007), at http://online.wsj.com/article/SB117280201669024334.html. 89. T. S. Eliot, "Little Gidding," in Collected Poems 1909-1962 (Boston: Harcourt, Brace, 1963) 208: "We shall not cease from exploration/And the end of all our exploring" /Will be to arrive where we started/And know the place for the first time."

90. William A. Galston, Liberal Pluralism: The Implications of Values Pluralism for Political Theory and Practice (New York: Cambridge University Press, 2002) 105.

91. Troxel v. Granville, 530 U.S. at 89 (Stevens, J., dissenting).

92. Cf. Dwyer, "Parents' Religion and Children's Welfare: Debunking the Doctrine of Parents' Rights," 1389 ("[L]ower courts have continued to advance an interpretation of free exercise rights that effectively treats children as non-consenting 
instruments or means to the achievement of other persons' ends, rather than as persons in their own right, with interests of their own that are deserving of equal respect").

93. Cf. Ira C. Lupu, "Home Education, Religious Liberty, and the Separation of Powers," B.U. L. Rev. 67 (1987): 971, 976-77 ("The legal tradition of authorizing parents to speak for their offspring need not become a device by which children are made to disappear. Children, not fully competent to make decisions because of insufficient awareness of the decisions' long-term consequences, are normally subject to parental control. Parents are presumptively trustworthy decisionmakers for their children because parents generally feel affection for their young and are knowledgeable about their interests. Custodial power of this sort is never absolute, however, for it is based on a theory of fiduciary obligation. If the custodian mistreats his ward, public or private remedies designed to protect the child may be available"); cf. also S. Brennan and R. Noggle, "The Moral Status of Children: Children's Rights, Parents' Rights, and Family Justice," Social Theory and Practice 23 (1997): 1; Richard Arneson and Ian Shapiro, "Democratic Autonomy and Religious Freedom: A Critique of Wisconsin v. Yoder," in Democracy's Place (Ithaca: Cornell University Press, 1996) 137; Elizabeth S. Scott and Robert E. Scott, "Parents as Fiduciaries," Va. L. Rev. 81 (1995): 2401; Barbara Bennett Woodhouse, “'Out of Children's Needs, Children's Rights': The Child's Voice in Defining the Family," BYU J. Pub. L. 8 (1994): 321, and "Hatching the Egg: A Child-Centered Perspective on Parents' Rights," Cardozo L. Rev. 14 (1993): 1747; Jeffrey Blustein, Parents and Children: The Ethics of the Family (New York: Oxford University Press, 1982) 104-14. But see Thomas H. Murray, The Worth of a Child (Berkeley: University of California Press, 1996) 61 ("[P]arenthood as stewardship still has its shortcomings as a model for parent-child relations. As a description of a relationship, it connotes disinterestedness, selflessness, a sort of benign but emotionally distant concern for the welfare of the child. This fits poorly with the intensity, love, and intimacy we prize between parents and children”); cf. Martin Guggenheim, What's Wrong with Children's Rights (Cambridge: Harvard University Press, 2005) $37-38$ ("Security is also furthered because children grow up in an environment in which their parents know their decisions will not be subject to close scrutiny. Parents are encouraged to care for their children by receiving maximum discretion to carry out their responsibilities free from the worry that their behavior will be monitored and second-guessed by a third party").

94. Cf. Arneson and Shapiro, "Democratic Autonomy and Religious Freedom," 138 (" $[\mathrm{C}]$ hildren are in no sense the property of their parents. Although most people will find the claim thus stated unexceptionable, and few would go so far as to describe their children as their property, many of the convictions to which people find themselves drawn in thinking about the authority of parents over children 
nevertheless reflect the archaic idea that the child is the chattel of the parent [which once went hand in hand with the patriarchal idea that the wife is the chattel of the husband]"). But see Galston, Liberal Pluralism, 103 ("Everyone can agree that children are not the 'property' of their parents. Still, when I say that this child is 'mine,' I am both acknowledging responsibilities and asserting authority beyond what I owe or claim vis-à-vis children in general. As parent, I am more than the child's caretaker or teacher, and I am not simply a representative of the state delegated to prepare the child for citizenship"); Jeffrey Blustein, Care and Commitment: Taking the Personal Point of View (New York: Oxford University Press, 1991) 178 ("What matters to many parents is not just that they have a son or daughter-someone on whom they can shower affection, or who will support them in their old age, or who will extend the blood line or carry on the family name, and the like-but crucially that this child is theirs, in the sense that he or she is the product of their commitment to and concern for one another").

95. Transcript of Oral Argument at 8, Meyer v. Nebraska, 262 U.S. 390 (1923).

96. C. Fried, "Correspondence," Phil. G Pub. Aff. 6 (1977): 288-89, quoted in Thornburgh v. American College of Obstetricians and Gynecologists, 476 U.S. 747, 778 n.5 (1986) (Stevens, J., concurring).

97. Milton, Paradise Lost, in Complete Poems and Major Prose 467 (XII, 587).

98. John Milton, "Areopagitica," in Complete Poems and Major Prose, 727-28. 